\title{
Liver histopathology in Baltic flounder (Platichthys flesus) as indicator of biological effects of contaminants
}

\author{
Thomas Lang ${ }^{\mathrm{a}, *}$, Werner Wosniok ${ }^{\mathrm{b}}$, Janina Baršiene ${ }^{\mathrm{c}}$, Katja Broeg ${ }^{\mathrm{d}}$, \\ Justyna Kopecka ${ }^{\mathrm{e}}$, Jari Parkkonen ${ }^{\mathrm{f}}$ \\ ${ }^{a}$ Federal Research Centre for Fisheries, Institute of Fishery Ecology, Deichstrasse 12, 27472 Cuxhaven, Germany \\ ${ }^{\mathrm{b}}$ University of Bremen, Institute of Statistics, Bibliothekstrasse 1, 28334 Bremen, Germany \\ ${ }^{\mathrm{c}}$ Institute of Ecology of Vilnius University, Akademijos 2, 08412 Vilnius, Lithuania \\ d Alfred Wegener Institute for Polar and Marine Research, Am Handelsshafen 12, 27570 Bremerhaven, Germany \\ e Institute of Oceanology, Powstancow Warszawy 55, P.O. Box 197, 81-712 Sopot, Poland \\ ${ }^{\mathrm{f}}$ Gothenburg University, Box 463, 40530 Gothenburg, Sweden
}

\begin{abstract}
Results are presented of a study on liver histopathology in Baltic flounder (Platichthys flesus) carried out in 2001 and 2002 in four coastal sampling areas of the Baltic Sea: Kvädöfjärden (Swedish east coast, reference area), Klaipeda-Butinge (Lithuanian coast), Gulf of Gdansk (Polish coast), and Wismar Bay (German coast) within the framework of the EU-funded BEEP project. Liver lesions were diagnosed and categorised using standardised methodologies and, for a spatial and temporal assessment of the prevalence and types of lesions detected, a scoring system was applied, involving the calculation of mean histopathology lesion scores. $83.0 \%$ of the 436 female flounder examined (size range: $20-43 \mathrm{~cm}$ total length, age range: $2-8$ years) were affected by liver lesions, out of which $74.3 \%$ were assigned to the category of non-specific, $3.4 \%$ to the category of early toxicopathic non-neoplastic, $4.6 \%$ to the category of pre-neoplastic and $0.7 \%$ to the category of neoplastic lesions. Mean lesions scores were highest in the areas at the Lithuanian and Swedish coast and there is indication of an impact of the age structure of the flounder populations studied, the sampling season as well as of contaminant effects.
\end{abstract}

(C) 2005 Elsevier Ltd. All rights reserved.

Keywords: Platichthys flesus; Baltic Sea; Liver histopathology; Biological effects of contaminants

\section{Introduction}

Because of the growing evidence of a cause-effect relationship between environmental contaminants and the occurrence of toxicopathic liver lesions in fish (Malins et al., 1988; Köhler, 1990; Köhler et al., 1992; Stein et al., 1992; Vethaak and Rheinallt, 1992; Moore and Myers, 1994; Myers et al., 1991, 1992, 1994, 1998a,b; Vethaak et al., 1996; Stehr et al., 1998; Stentiford et al., 2003; Feist et al., 2004), studies on liver histopathology in fish have increasingly been incorporated in national mar-

\footnotetext{
* Corresponding author. Tel.: +49 4721 38034; fax: +49 472153583.

E-mail address: thomas.lang@ifo.bfa-fisch.de (T. Lang).
}

ine biological effects monitoring programmes (Lang, 2002a; Feist et al., 2004). On an international level, such studies are in the process of being implemented in integrated environmental monitoring and assessment programmes, e.g., as part of the OSPAR Coordinated Environmental Monitoring Programme (CEMP) for the northeast Atlantic (OSPAR, 2004). Through efforts of the International Council for the Exploration of the Sea (ICES) and the formerly EU-funded project Biological Effects Quality Assurance in Monitoring Programmes (BEQUALM), guidelines for methodologies to be used for monitoring histopathological liver lesions have been developed and partly intercalibrated between laboratories (ICES, 1997; Lang, 2002b; Feist et al., 2004; BEQUALM, 2005). These guidelines have been adopted by OSPAR and have been incorporated 
in the Guidelines/Technical Annexes of the OSPAR Joint Assessment and Monitoring Programme (JAMP) for general and for PAH-specific biological effects monitoring (OSPAR, 1997, 2003, 2004).

The majority of studies on liver histopathology in flatfish species in relation to contaminants has been carried out in coastal waters of the USA (e.g., Malins et al., 1985a,b, 1988; Myers et al., 1991, 1992, 1994, 1998a,b; Stein et al., 1992; Moore et al., 1997; Stehr et al., 1998) and in the North Sea (e.g., Kranz and Dethlefsen, 1990; Bucke and Feist, 1993; Köhler, 1990; Köhler et al., 1992; Vethaak and Wester, 1996; Lang, 2002b; Stentiford et al., 2003). For the Baltic Sea, there is only limited information available, largely resulting from data generated within the 1994 ICES/BMB Workshop on Fish Diseases and Parasites in the Baltic Sea (Lang and Mellergaard, 1999; Lang et al., 1999; Bogovski et al., 1999) and some national studies (Bogovski, 1994; Lang and Dethlefsen, 1994; Wiklund and Bylund, 1994). These studies focused on the European flounder (Platichthys flesus) as target species because of its abundance and wide distribution in the Baltic Sea (Aro, 1989) and were largely conducted according to ICES standard methodologies, involving a quantification of macroscopically visible liver nodules $>2 \mathrm{~mm}$ in diameter and a subsequent histological confirmation of the neoplastic nature of the lesions (ICES, 1989, 1997; Bucke et al., 1996; Feist et al., 2004).

In the present study, which was part of the EU-funded project Biological Effects of Environmental Pollution in Marine Coastal Ecosystems (BEEP) (Lehtonen and Schiedek, this volume; Lehtonen et al., this volume), a different approach was applied. Liver tissue samples were taken randomly from a defined number of flounder from four coastal sampling areas in the Baltic Sea (Swedish east coast, Lithuanian coast, Gulf of Gdansk, Wismar Bay) and were studied histologically for the presence of a wider range of lesions. The categories of liver lesions included in the examination are widely accepted as useful indicators for monitoring biological effects of environmental stressors, in particular contaminants, and ranged from non-specific lesions with a largely unclear linkage to contaminants to early toxicopathic non-neoplastic, pre-neoplastic, benign neoplastic and malignant neoplastic lesions, known to be associated with exposure to carcinogenic or non-carcinogenic contaminants (Malins et al., 1988; Myers et al., 1994; Vethaak et al., 1996; ICES, 1997; Feist et al., 2004). A scoring system was applied, the basic assumption of which is an increasing likelihood for a linkage to contaminant exposure (carcinogenic compounds in particular) from non-specific lesions to malignant tumours.

The aims of the present study were to provide baseline data on the prevalence of histopathological liver lesions in Baltic flounder and to compare the sampling areas in terms of the types and prevalence of lesions present, in the light of potential host-specific (fish size, age) and sitespecific (contaminants) spatial and temporal effects, by using a widely applicable and robust categorisation and scoring system designed for monitoring purposes.

\section{Materials and methods}

Flounder were collected in four coastal sampling areas: Kvädöfjärden, Swedish east coast (reference); KlaipedaButinge area, Lithuanian coast; Gulf of Gdansk, coast of Poland and Wismar Bay, German coastal waters, by either bottom trawling or standing gears (the latter only at Kvädöfjärden). Samples were taken within four campaigns in spring 2001 (campaign 1), autumn 2001 (campaign 2), spring 2002 (campaign 3) and autumn 2002 (campaign 4), as described in Lehtonen and Schiedek (this volume). In each of the areas, up to three sampling stations were visited per campaign (Kvädöfjärden: only one station; Lithuanian coast: Butinge, Nemirseta, Palanga; Gulf of Gdansk: Mechelinki, Sobieszewo, Sopot; Wismar Bay: Wismar Harbour, Walfisch, Offentief), characterised by different contaminant exposure conditions (Baršiene et al., this volume; Kopecka et al., this volume; Schiedek et al., this volume; BEEP, unpublished data). Information on size and age spectrum of the flounder sampled is provided in Table 1.

Only live female flounder were processed for histology, either immediately after catching or after being kept alive in tanks with running seawater of ambient water temperature. Fish were sacrificed by a blow on the head, followed by decapitation, and were dissected. Histological sampling and further processing were performed according to standard procedures (Feist et al., 2004). Liver tissue samples (max $2 \mathrm{~mm}$ thick) were cut from the central part of the organ using a scalpel, placed into labelled histological cassettes, fixed in $10 \%$ neutral buffered formalin and transferred to $70 \%$ ethanol after $24-48 \mathrm{~h}$. This was followed by dehydration of tissue samples, embedding in paraffin, sectioning at 3-4 $\mu \mathrm{m}$ using a rotary microtome and staining with haematoxylin and eosin. Four liver sections from each tissue sample were inspected by means of light microscopy. Otoliths were removed for subsequent age determination. From the same fish, various samples were obtained for other biological effects measurements the results of which are reported elsewhere (Baršiene et al., this volume; Broeg and Lehtonen, this volume; Kopecka et al., this volume; Lehtonen et al., this volume; Vuorinen et al., this volume).

Histopathological liver lesions detected were assigned to five main categories recommended for monitoring biological effects of contaminants in flatfish species: non-specific lesions, early toxicopathic non-neoplastic lesions, pre-neoplastic lesions, benign neoplasms and malignant neoplasms (see Table 2) (Feist et al., 2004). Lesions recorded were further staged into mild, medium and severe, depending on the size of the tissue area affected in the sections and the degree of cellular change observed. A scoring systems consisting of 15 scores was applied (see Table 2) and was used for the assessment of spatial and temporal variation in the lesions recorded. After inspection of the liver sections, each fish was assigned a score dependent on the type and severity of the lesion recorded. If more than one lesion category was recorded in one specimen, the highest out of the single 
Table 1

Total length $(\mathrm{cm})$ and age (years) of female Baltic flounder (Platichthys flesus) by sampling area, sampling station within area and by campaign

\begin{tabular}{|c|c|c|c|c|c|c|c|}
\hline \multirow[t]{2}{*}{ Area } & \multirow[t]{2}{*}{ Station } & & & \multicolumn{4}{|l|}{ Campaign } \\
\hline & & & & 1 (spring 2001) & 2 (autumn 2001) & 3 (spring 2002) & 4 (autumn 2002) \\
\hline \multirow[t]{5}{*}{ Kvädöfjärden } & \multirow[t]{5}{*}{-} & $N$ & Length/age & $-1-$ & $20 / 20$ & $20 / 20$ & $20 / 20$ \\
\hline & & Length & Mean \pm S.D. & - & $31.4 \pm 1.9$ & $27.2 \pm 3.3$ & $30.3 \pm 3.1$ \\
\hline & & & Range & - & $28-34$ & $23-34$ & $23-35$ \\
\hline & & Age & Mean \pm S.D. & - & $4.0 \pm 0.7$ & $3.9 \pm 0.9$ & $4.1 \pm 0.9$ \\
\hline & & & Range & - & $3-5$ & $3-6$ & $3-6$ \\
\hline \multirow[t]{15}{*}{ Lithuanian coast } & \multirow[t]{5}{*}{ Butinge } & $N$ & Length/age & $-1-$ & $-1-$ & $18 / 18$ & $20 / 20$ \\
\hline & & Length & Mean \pm S.D. & - & - & $29.6 \pm 4.8$ & $25.1 \pm 4.2$ \\
\hline & & & Range & - & - & $20-38$ & $20-33$ \\
\hline & & Age & Mean \pm S.D. & - & - & $4.1 \pm 0.9$ & $3.4 \pm 0.9$ \\
\hline & & & Range & - & - & $3-6$ & $2-5$ \\
\hline & \multirow[t]{5}{*}{ Nemirseta } & $N$ & Length/age & $-1-$ & $-1-$ & $20 / 19$ & $20 / 20$ \\
\hline & & Length & Mean \pm S.D. & - & - & $35.2 \pm 3.5$ & $27.3 \pm 5.7$ \\
\hline & & & Range & - & - & $29-43$ & $20-37$ \\
\hline & & Age & Mean \pm S.D. & - & - & $6.1 \pm 1.1$ & $3.5 \pm 1.2$ \\
\hline & & & Range & - & - & $4-8$ & $2-6$ \\
\hline & \multirow[t]{5}{*}{ Palanga } & $N$ & Length/age & $-1-$ & $-1-$ & $16 / 15$ & $20 / 20$ \\
\hline & & Length & Mean \pm S.D. & - & - & $30.6 \pm 4.7$ & $28.8 \pm 3.8$ \\
\hline & & & Range & - & - & $21-36$ & $24-37$ \\
\hline & & Age & Mean \pm S.D. & - & - & $4.4 \pm 1.0$ & $3.6 \pm 1.1$ \\
\hline & & & Range & - & - & $3-6$ & $2-6$ \\
\hline \multirow[t]{15}{*}{ Gulf of Gdansk } & \multirow[t]{5}{*}{ Mechelinki } & $N$ & Length/age & $-1-$ & $19 / 18$ & $20 / 20$ & $20 / 20$ \\
\hline & & Length & Mean \pm S.D. & - & $26.7 \pm 1.8$ & $28.0 \pm 1.7$ & $28.4 \pm 1.3$ \\
\hline & & & Range & - & $23-30$ & $24-30$ & $25-30$ \\
\hline & & Age & Mean \pm S.D. & - & $2.5 \pm 0.5$ & $3.5 \pm 0.5$ & $3.0 \pm 0.7$ \\
\hline & & & Range & - & $2-3$ & $3-4$ & $2-4$ \\
\hline & \multirow[t]{5}{*}{ Sobieszewo } & $N$ & Length/age & $-1-$ & $20 / 19$ & $19 / 19$ & $20 / 20$ \\
\hline & & Length & Mean \pm S.D. & - & $27.2 \pm 1.7$ & $26.5 \pm 2.0$ & $28.1 \pm 1.7$ \\
\hline & & & Range & - & $24-30$ & $23-30$ & $24-30$ \\
\hline & & Age & Mean \pm S.D. & - & $2.7 \pm 0.5$ & $3.4 \pm 0.5$ & $2.6 \pm 0.6$ \\
\hline & & & Range & - & $2-3$ & $3-4$ & $2-4$ \\
\hline & \multirow[t]{5}{*}{ Sopot } & $N$ & $\mathrm{~N}$ length/age & $-1-$ & $20 / 20$ & $20 / 19$ & $20 / 20$ \\
\hline & & Length & Mean \pm S.D. & - & $27.7 \pm 1.2$ & $27.0 \pm 1.9$ & $26.3 \pm 2.1$ \\
\hline & & & Range & - & $26-30$ & $24-30$ & $24-31$ \\
\hline & & Age & Mean \pm S.D. & - & $2.9 \pm 0.5$ & $3.0 \pm 0.6$ & $2.7 \pm 0.6$ \\
\hline & & & Range & - & $2-4$ & $2-4$ & $2-4$ \\
\hline \multirow[t]{15}{*}{ Wismar Bay } & \multirow[t]{5}{*}{ Wismar Harbour } & $N$ & Length/age & $8 / 8$ & $-1-$ & $2 /-$ & $-1-$ \\
\hline & & Length & Mean \pm S.D. & $29.6 \pm 7.1$ & - & $24.0 \pm 5.7$ & - \\
\hline & & & Range & $23-39$ & - & $20-28$ & - \\
\hline & & Age & Mean \pm S.D. & $3.1 \pm 1.4$ & - & - & - \\
\hline & & & Range & $2-5$ & - & - & - \\
\hline & \multirow[t]{5}{*}{ Walfisch } & $N$ & Length/age & $20 / 19$ & $20 / 18$ & $20 /-$ & $-1-$ \\
\hline & & Length & Mean \pm S.D. & $31.2 \pm 3.2$ & $29.9 \pm 2.5$ & $26.8 \pm 2.8$ & - \\
\hline & & & Range & $26-37$ & 24-34 & $22-34$ & - \\
\hline & & Age & Mean \pm S.D. & $3.0 \pm 0.8$ & $2.8 \pm 0.4$ & - & - \\
\hline & & & Range & $2-5$ & $2-3$ & - & - \\
\hline & \multirow[t]{5}{*}{ Offentief } & $N$ & Length/age & $11 / 11$ & $-1-$ & $3 / 0$ & $-1-$ \\
\hline & & Length & Mean \pm S.D. & $28.9 \pm 4.1$ & - & $27.7 \pm 2.1$ & - \\
\hline & & & Range & $25-35$ & - & $26-30$ & - \\
\hline & & Age & Mean \pm S.D. & $2.9 \pm 0.9$ & - & - & - \\
\hline & & & Range & $2-5$ & - & - & - \\
\hline
\end{tabular}

$N$ : number examined; Mean: arithmetic mean; S.D.: standard deviation; Range: min-max; -: no sampling/missing values.

scores was used for assessment purposes. From the individual scores, mean liver lesion scores (medians) were calculated for each sampling station and time.

For the statistical analysis of the relationship between lesion scores and potentially explanatory factors, a multinomial logistic model accounting for the rank structure of the scores was developed (Hosmer and Lemeshow,
2000). Explaining quantities tested for inclusion into the model were area, station within area, age, size (as total length), campaign and interaction terms for campaign and area as well as for area and age. Terms included in the final model were selected by a stepwise forward/backward procedure, using a $5 \%$ error level for decisions on inclusion or removal. Other test decisions were also based 
Table 2

Categories of histopathological liver lesions in flatfish species (modified after Feist et al., 2004) and scoring system used for their quantification in Baltic flounder (Platichthys flesus)

\begin{tabular}{|c|c|c|c|c|}
\hline \multicolumn{2}{|c|}{ Lesion categories } & \multirow{2}{*}{$\begin{array}{l}\text { Lesions } \\
-\end{array}$} & \multirow{2}{*}{$\begin{array}{l}\text { Lesion stages } \\
-\end{array}$} & \multirow{2}{*}{$\begin{array}{l}\text { Lesion scores } \\
0\end{array}$} \\
\hline 0 & No anomaly detected & & & \\
\hline 1 & Non-specific lesions & $\begin{array}{l}\text { Inflammatory change (infiltration, granulomatosis) } \\
\text { Degenerative change (coagulative or single cell necrosis, atrophy) } \\
\text { Proliferative change (hepatocellular regeneration, fibrosis, bile duct hyperplasia) } \\
\text { Increased number/area of macrophage aggregates } \\
\text { Lipoidosis } \\
\text { Parasites }\end{array}$ & $\begin{array}{l}\text { Mild } \\
\text { Medium } \\
\text { Severe }\end{array}$ & $\begin{array}{l}1 \\
2 \\
3\end{array}$ \\
\hline 2 & $\begin{array}{l}\text { Early toxicopathic } \\
\text { non-neoplastic lesions }\end{array}$ & $\begin{array}{l}\text { Hepatocellular/nuclear pleomorphism } \\
\text { Hydropic vacuolation (hepatic/biliary/pancreatic) } \\
\text { Phospholipidosis of hepatocytes } \\
\text { Fibrillar inclusions } \\
\text { Peliosis and spongiosis hepatis }\end{array}$ & $\begin{array}{l}\text { Mild } \\
\text { Medium } \\
\text { Severe }\end{array}$ & $\begin{array}{l}4 \\
5 \\
6\end{array}$ \\
\hline 3 & Pre-neoplastic lesions & $\begin{array}{l}\text { Foci of cellular alteration } \\
\text { Clear cell } \\
\text { Vacuolated } \\
\text { Eosinophilic } \\
\text { Basophilic } \\
\text { Mixed }\end{array}$ & $\begin{array}{l}\text { Mild } \\
\text { Medium } \\
\text { Severe }\end{array}$ & $\begin{array}{l}7 \\
8 \\
9\end{array}$ \\
\hline 4 & Benign neoplasms & $\begin{array}{l}\text { Hepatocellular adenoma } \\
\text { Cholangioma } \\
\text { Haemangioma } \\
\text { Pancreatic acinar cell adenoma } \\
\text { Other }\end{array}$ & $\begin{array}{l}\text { Mild } \\
\text { Medium } \\
\text { Severe }\end{array}$ & $\begin{array}{l}10 \\
11 \\
12\end{array}$ \\
\hline 5 & Malignant neoplasms & $\begin{array}{l}\text { Hepatocellular carcinoma } \\
\text { Cholangiocarcinoma } \\
\text { Pancreatic acinar cell carcinoma } \\
\text { Haemangiocarcinoma } \\
\text { Other }\end{array}$ & $\begin{array}{l}\text { Mild } \\
\text { Medium } \\
\text { Severe }\end{array}$ & $\begin{array}{l}13 \\
14 \\
15\end{array}$ \\
\hline
\end{tabular}

Note: Only lesions in italics were recorded in the present study.

on a $5 \%$ error level. All calculations were performed using the SAS/STAT ${ }^{\circledR}(9.13)$ software.

\section{Results}

In total, liver sections of 436 female flounder were analysed for the presence of histopathological lesions. By using the scoring system, $74.3 \%$ of all specimens were categorised as being afflicted with non-specific lesions only (scores 1-3), $3.4 \%$ with early toxicopathic non-neoplastic lesions (scores 4-6), 4.6\% with pre-neoplastic lesions (scores 7-9) and $0.7 \%$ with benign tumours (scores 10-12). Malignant tumours (scores 13-15) were not detected. Within the category of non-specific lesions, degenerative changes (coagulative or single cell necrosis) (239 cases, prevalence range 29.4-77.5\%, depending on sampling area and station, campaigns combined) and proliferative changes (hepatocellular regeneration) (209 cases, prevalence range 21.7-76.3\%) were predominating, followed by inflammatory change such as infiltration (126 cases, prevalence range 0.0 $38.3 \%$ ) and granulomatosis (77 cases, prevalence range $0.0-30.0 \%$ ), the latter in most cases associated with parasitic infestation (nematodes and acanthocephaleans). Increased melanomacrophage aggregates were recorded in
49 cases (prevalence range $0.0-35.0 \%$ ). Only comparatively few clear cases of lesions categorised as early toxicopathic non-neoplastic lesions were recorded, consisting of cellular/nuclear pleomorphism (one case, prevalence range $0.0-1.7 \%$ ) and hepatocellular or biliary hydropic vacuolation (18 cases, prevalence range $0.0-17.5 \%$ ). Amongst the pre-neoplastic lesions (foci of cellular alteration) recorded, vacuolated foci (18 cases, prevalence range $0.0-11.7 \%$ ) were dominating, followed by basophilic foci (5 cases, prevalence range $0.0-5.0 \%$ ). Only two cases of clear cell foci (prevalence range $0.0-2.5 \%$ ) and one case of eosinophilic foci (prevalence range $0.0-2.5 \%$ ) were recorded. All three cases of benign neoplasms detected were diagnosed as hepatocellular adenoma (prevalence range $0.0-2.6 \%$ ). Information on other types of lesions detected is provided in Table 2.

From the confidence intervals of the prevalences displayed in Fig. 1 it can be seen that flounder from the Gulf of Gdansk and Wismar Bay were significantly less affected by any kind of lesion than flounder from Kvädöfjärden and from the Lithuanian coast. The prevalence of preneoplastic lesions (category 3) was significantly higher at Kvädöfjärden and at the Lithuanian coast compared to the Gulf of Gdansk and the Wismar Bay. For the non- 


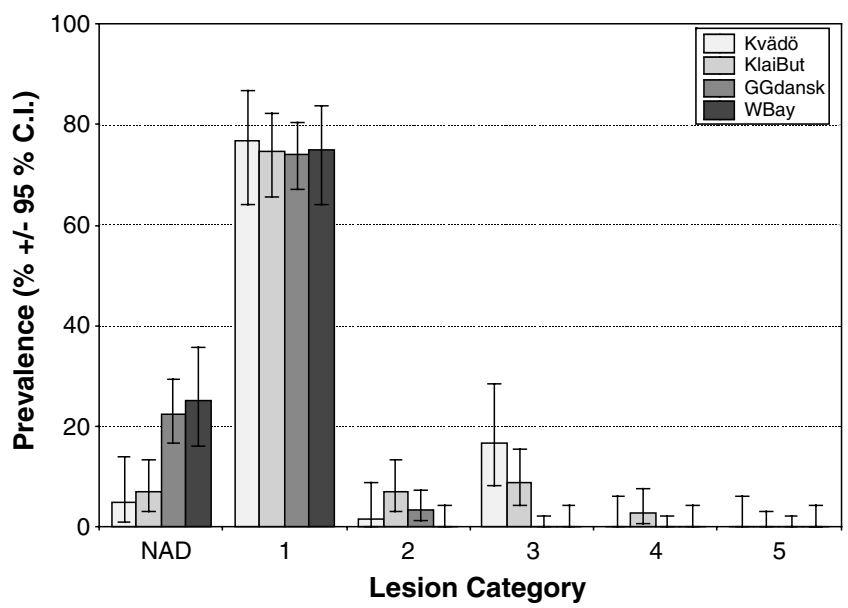

Fig. 1. Prevalence (with $95 \%$ confidence intervals) of histopathological liver lesions in Baltic flounder (Platichthys flesus) according to lesion category (NAD: no anomaly detected; 1: non-specific lesions; 2: early toxicopathic non-neoplastic lesions; 3: pre-neoplastic lesions; 4: benign neoplasms; 5: malignant neoplasms) and sampling area (Kvädö: Kvädöfjärden, Sweden (reference); KlaiBut: Klaipedea-Butinge, Lithuania; GGdansk 4: Gulf of Gdansk, Poland; WBay: Wismar Bay, Germany).

specific (category 1), the early toxicopathic non-neoplastic (category 2) and the benign neoplastic lesions (category 4) (the latter recorded only at the Lithuanian coast) there were no significant differences between sampling areas.

Fig. 2 provides information on mean lesion scores by area, sampling station within area and by campaign, by using box and whisker plots with medians as scores. In accordance to Fig. 1, the highest scores were obtained at sampling stations at Kvädöfjärden and at the Lithuanian coast, with mean scores of 2.0 and ranging from 1.0 to 3.0, respectively. Mean scores at stations in the Gulf of Gdansk and in the Wismar Bay ranged from 0.0 to 2.0 and from 0.5 to 2.0, respectively. Mild, medium and severe non-specific lesions (lesion scores 1-3) were present in all sampling areas/stations and campaigns, early toxicopathic non-neoplastic lesions (lesion scores 4-6) in all areas except the Wismar Bay and in most campaigns, pre-neoplastic lesions (lesion scores 7-9) only at all stations at Kvädöfjärden and at the Lithuanian coast, and neoplastic lesions (lesions cores 10-12) only at two stations within the area at the Lithuanian coast (Butinge, Nemirseta).

Because of the obvious regional differences in the size/ age spectrum of the flounder sampled (see Table 1), a statistical analysis on effects of size (as total length) and age on the lesion scores was performed by using a multinomial model as described above. Other potentially explanatory factors besides size and age considered in the modelling process were sampling area, station within area, campaign and interaction terms for campaign and area as well as for area and age. After adjusting for effects of the other explanatory quantities considered in the analysis, a significant (positive) effect of age ( $p=0.0055)$ was found, indicating an increase in scores with increasing age of the fish. The incorporation of size into the model did not result in an improvement of the model fit.

Despite the strong impact of age, the sampling area still had a significant effect on the lesion scores after adjusting for effects of the other explanatory quantities (including size and age). The adjusted scores recorded at Kvädöfjärden

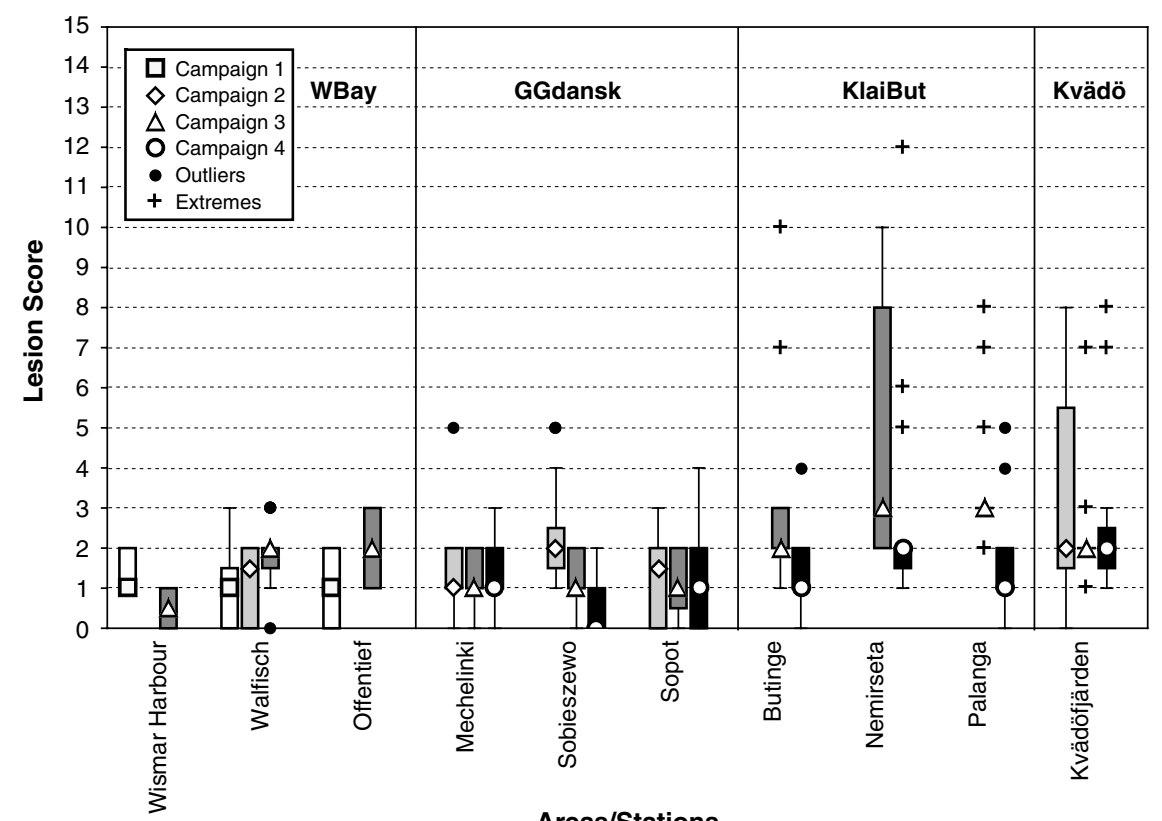

Fig. 2. Mean histopathology liver lesion scores (symbols in boxes: medians; boxes: quartiles; whiskers: ranges without outliers; crosses: outliers; asterisks: extremes) in female Baltic flounder (Platichthys flesus) by sampling area, sampling station within area and by sampling campaign (Kvädö: Kvädöfjärden, Sweden (reference); KlaiBut: Klaipedea-Butinge, Lithuania; GGdansk: Gulf of Gdansk, Poland; WBay: Wismar Bay, Germany) (for explanation of lesion scores, see Table 2). 
and the Lithuanian coast were significantly higher than those in the Gulf of Gdansk and the Wismar Bay $(p<$ 0.0001 in all cases), while there were no significant differences between Kvädöfjärden and the Lithuanian coast and the Gulf of Gdansk and the Wismar Bay, respectively.

Significant effects of stations within sampling areas were only found at the Lithuanian coast, with scores at station Nemirseta being significantly higher compared to scores at station Palanga $(p=0.0004)$.

A full model incorporating the interaction terms between campaign and sampling area could not be fitted due to a lack of data (see Table 1). However, a grouping of campaigns by season (campaigns 1 and $3=$ spring; campaigns 2 and $4=$ autumn) resulted in significant differences in the Gulf of Gdansk (scores higher in autumn than in spring, $p=0.0258$ ) and at the Lithuanian coast (scores higher in spring than in autumn, $p<0.0001$ ).

\section{Discussion}

The occurrence of liver lesions considered to be associated with exposure to anthropogenic contaminants has been recorded before in European flounder from coastal areas of the North Sea and the Irish Sea (Peters et al., 1987; Köhler, 1990; Vethaak et al., 1996; Vethaak and Wester, 1996; Köhler and Van Norden, 1998; Stentiford et al., 2003) as well as from the Baltic Sea (Bogovski, 1994; Wiklund and Bylund, 1994; Bogovski et al., 1999; Lang et al., 1999). For the Baltic Sea, however, the present study is the first to our knowledge focusing not only on macroscopically visible pre-neoplastic and neoplastic lesions but also on other types of histopathological liver changes.

Although all histopathologies found in the present study have been described before by other authors (see above), it is interesting to note that the prevalences of the lesions seem to vary considerably between geographical areas investigated. For instance, some lesions known to be prevalent in flounder from the North Sea and Irish Sea could not or only rarely be found in Baltic flounder. An example is fibrillar inclusion, which occurred at a prevalence up to 80\% (mean 27.6\%) in UK estuaries (often associated with nuclear and cellular pleomorphism) (Stentiford et al., 2003) but was not at all recorded in the present study. In the same study, the prevalence of pre-neoplastic lesions (foci of cellular alteration) reached a maximum value of $43.3 \%$ (mean $19.0 \%$ ) and was, thus, considerably higher compared to the one recorded in the present study (overall prevalence $6.0 \%$, including fish affected by both neoplastic and pre-neoplastic lesions and assigned to the category of benign neoplasms, scores 10-12; see Table 2). For flounder from the estuary of the river Elbe (North Sea), Köhler and Van Norden (1998) reported a prevalence of macroscopic liver neoplasms of up to $35 \%$. In flounder from sampling sites in coastal and estuarine waters of The Netherlands, histologically confirmed cases of neoplasms (adenomas and carcinomas) were present in $1.0 \%$ of flounder inspected for macroscopic liver nodules (Vethaak and Wester, 1996), the maximum prevalences, however, reached $30 \%$ in old specimens from certain sites within the same sampling area (Vethaak and Jol, 1996). In the present study, the prevalence of benign liver tumours was $0.7 \%$ and malignant tumours were absent.

The finding of a low prevalence of neoplastic lesions in the current study corresponds to results of previous work carried out in the Baltic Sea. Bogovski (1994), e.g., recorded a prevalence of neoplastic and pre-neoplastic lesions of $2.7 \%$ in flounder from Estonian waters off Tallinn. Bogovski et al. (1999) histologically examined macroscopic liver nodules from 34 Baltic flounder on a transect from Kiel Bight (westernmost Baltic Sea) to Estonian waters in the Gulf of Finland and found pre-neoplastic (basophilic, eosinophilic, clear cell foci) and neoplastic lesions (hepatocellular adenoma) with a mean prevalence (combined) of $0.9 \%$. The prevalence of macroscopical liver nodules $>2 \mathrm{~mm}$ in diameter (not examined histologically) on the same transect ranged from $0.0 \%$ to $4.0 \%$, depending on the sampling site (Lang et al., 1999). Wiklund and Bylund (1994) reported prevalences of macroscopic liver nodules (not examined histologically) of up to $10 \%$ in coastal waters of southwestern Finland.

These data strongly indicate that flounder from the Baltic Sea are less afflicted with lesions considered to be associated to contaminant exposure (early toxicopathic non-neoplastic, pre-neoplastic and neoplastic lesions) in general. Reasons for this are not obvious. One could be that flounder in the North Sea and Irish Sea spend longer periods of the year in coastal and estuarine habitats and may, thus, be more continuously exposed to contaminants from land-based sources than flounder in the Baltic Sea which undertake longer lasting seasonal spawning migrations to offshore areas (Aro, 1989) generally regarded as less contaminated. On the other hand, concentrations of contaminants (in particular of PAHs) are known to be comparatively high in Baltic Sea sediments, partly because of high total organic carbon (TOC) levels (Theobald, unpublished data). Other possible explanations for the marked geographical differences may be genetic effects on susceptibility, adaptation processes or an impact of the physical and chemical environment on the bioavailability, biotransformation and detoxification of contaminants. It is interesting to note in this context that extremely low prevalences of pre-neoplastic and neoplastic lesions $(<1 \%)$ have also been recorded in the common dab (Limanda limanda) from the western Baltic Sea (Lang, unpublished data). This species also show much higher prevalences in various North Sea areas (Kranz and Dethlefsen, 1990; Lang, 2002b).

Despite the generally low prevalence of toxicopathic liver lesions recorded in the present study, there is still indication for the presence of significant regional differences. The lesion scores were higher in the sampling areas at Kvädöfjärden and at the Lithuanian coast than in the other 
areas and pre-neoplastic and neoplastic lesions were restricted to stations within these two areas. One possible explanation for this pattern are differences in the size/age structure of the populations studied, with specimens collected at Kvädöfjärden and at the Lithuanian coast covering a wider size and age range and being bigger and older on average than those from the Gulf of Gdansk and Wismar Bay (see Table 1). It is well known from other studies in flounder that age and length are risk factors for the occurrence especially of neoplastic lesions (Köhler, 1990; Vethaak and Jol, 1996; Vethaak and Wester, 1996; Stentiford et al., 2003) and, therefore, the data of the present study were statistically analysed for such effects by using a multinomial logistic model. The results indeed revealed a significant effect of age on the lesion scores, whilst the incorporation of size (total length) into the model did not result in an improvement of the model fit. It is interesting to note that an area-specific effect of age was not found to contribute significantly to the model fit. This indicates that a general age effect, i.e. the same dependency between age and lesion score (as expressed by the regression slope of the function but not necessarily by the score values), existed in all sampling areas.

Despite the significant age effects, the model results provided evidence that, after adjusting for age effects, the sampling area itself remained to have a significant effect on the score, highlighting that other area-specific factors must have also played a role. For the sampling area in the Lithuanian coastal zone there is information available supporting the hypothesis that contaminant exposure due to an accidental oil spill in the Butinge oil terminal and harbour dredging activities in Klaipeda port, both occurring in 2001, may have been causally involved in the relatively high lesion scores observed especially during campaign 3 in spring 2002 (Baršiene et al., this volume) (see Fig. 2). According to the same authors, this area can be regarded as polluted in general, e.g., the Nemirseta station is affected by contamination from the Nemunas River basin, repeated dredging in Klaipeda port and dumping, and the Butinge station is under the influence of municipal sewage discharge as well as contamination from Mažeikiai oil refinery plant and the Butinge oil terminal. This is also reflected in the higher concentrations of organic contaminants (PCBs, $\mathrm{HCH}, \mathrm{HCB}, \mathrm{DDT}$ and its metabolites, PBDE) in flounder from the area at the Lithuanian coast compared to other areas (Baršiene et al., this volume; Kopecka et al., this volume; BEEP, unpublished data). In contrast, there is no evidence of elevated concentrations of PAH metabolites in bile from flounder collected in the Lithuanian area compared to the other areas (Vuorinen et al., this volume). The assumption of a potential role of contaminants is further strengthened by the results of the other biomarker measurements in the same individuals examined for liver lesions, clearly revealing significant biomarker responses attributed to contaminant effects (Baršiene et al., this volume). In the reference area Kvädöfjärden at the Swedish coast, however, contaminant effects are unlikely to have played a major role because this area is considered relatively unpolluted and has, therefore, been used as reference location not only in the BEEP project but also in the Swedish National Marine Monitoring Programme (Sandström et al., 2004). However, contaminant data from flounder sampled within the BEEP project in the same area at more offshore locations did not reveal lower concentrations of organic contaminants compared to other BEEP offshore sites (BEEP, unpublished data). The same holds true for the measurement of PAH metabolites (Lang et al., in preparation). In addition, there is evidence from long-term studies for increased levels of EROD in viviparous blenny (Zoarces viviparus) (Förlin, pers. communication) and for increased levels of metallothioneins in flounder from this area (Lehtonen, pers. communication).

The fact that significant effects of stations within sampling areas were only found at the Lithuanian coast, with scores at station Nemirseta being significantly higher compared to scores at station Palanga (see Fig. 2), indicates that there were no major effects of the known or suspected contaminant gradients within the areas on the lesion scores recorded.

Significant seasonal effects on the lesions scores were identified in the Gulf of Gdansk and, very clearly, at the Lithuanian coast with autumn scores being higher than spring scores and vice versa (see Fig. 2). It cannot be excluded that these differences were associated with seasonal spawning and feeding migrations of the flounder. Spawning of the flounder populations inhabiting this area (ICES Subdivision 26) takes place in the period March to June (Aro, 1989) and, thus, the spring sampling (April in the Gulf of Gdansk and June at the Lithuanian coast) was performed during and the autumn sampling (October in the Gulf of Gdansk and September at the Lithuanian coast) outside the spawning season (Kopecka et al., this volume; Baršiene et al., this volume). Particularly the marked differences in size and age of the flounder from the stations at the Lithuanian coast between spring and autumn (see Table 1) indicate a different composition of the population, possibly related to the migrations.

In contrast to the comparatively low prevalence of toxicopathic lesions recorded in the present study, a high prevalence of non-specific lesions (lesion category 1, see Fig. 1 and Table 2) were noted in all sampling areas. It has to be mentioned that all lesions detected microscopically were recorded, even those with a low severity. Particularly for the mild degenerative (necrosis) and regenerative changes (hepatocellular regeneration) (lesion score 1) it is likely that their occurrence largely reflects the normal "healthy" conditions and cannot be considered as indicator of a disturbed environment.

In any case, when interpreting the results of the present study, a common shortcoming of histopathological studies has to be taken into account, namely that the lesions found and the resulting scores very likely represent an underesti- 
mation of the real conditions because only small portions of the livers (four tissue section of 3-4 $\mu \mathrm{m}$ thickness from a liver tissue sample of varying size taken from a much larger liver) were examined. For comparing results of the current study on the prevalence of early toxicopathic nonneoplastic lesions with other published information it has furthermore to be considered that there might be interobserver variability especially for the identification of subtle changes, e.g., related to non-specific lesions, cellular and nuclear pleomorphism or phospholipidosis, which may involve a certain degree of subjectivity. In the present study, a conservative approach was applied and all uncertain cases were categorically ignored. For future studies, e.g., within internationally coordinated monitoring programmes, efforts regarding intercalibration and standardisation should, therefore, be enhanced. The BEQUALM programme with its liver histopathology component is considered a major step into this direction (BEQUALM, 2005). In this context, the scoring system applied in the present study and the calculation of mean histopathology lesion scores can be regarded as a useful approach, because it results in quantitative and combined figures that can be used as health indicators in temporal and spatial monitoring and assessments. The basic assumption behind the scoring system is an increasing likelihood for a linkage to contaminant exposure from non-specific lesions (low scores) to malignant tumours (highest scores), with particular emphasis on effects of carcinogenic compounds. Therefore, it will have to be tested if this approach can also be used in cases where other, e.g., immunotoxic, compounds are suspected to be main causes of histopathological liver lesions in fish.

It can be concluded from the results of the present study that liver histopathology conducted according to standardised procedures is a useful tool to be incorporated in monitoring programmes assessing the health of the Baltic ecosystem and the role of contaminants. It is considered as essential that these studies are part of an integrated programme, combining chemical (contaminants), biological (biomarkers and host-specific parameters, e.g., length and age) and oceanographic measurements with appropriate statistical techniques (such as the multifactorial logistic modelling applied in the present study) required to more fully understand the complex interactions of biotic and abiotic factors involved.

\section{Acknowledgements}

This work was supported by the European Commission (Research Directorate General, Environment ProgramMarine Ecosystems) through the BEEP project "Biological Effects of Environmental Pollution in Marine Coastal Ecosystems" (contract EVK3-CT2000-00025). Technical assistance of U. Kürschner, S. Reysen, B. Fleck and all colleagues involved in the sampling of fish and the useful comments made by two anonymous reviewers are gratefully acknowledged.

\section{References}

Aro, E., 1989. A review of fish migration patterns in the Baltic Sea. Rapport et Procès-Verbaux des Réunions, Conseil international pour L'Exploration de la Mer 190, 72-96.

Baršiene, J., Lehtonen, K.K., Köhler, A., Broeg, K., Vuorinen, P.J., Lang, T., Pempkowiak, J., Syvokiené, J., Dedonyte, V., Rybakovas, A., Repečka, R., Vuontisjärvi, H., Kopecka, J., this volume. Biomarker responses in flounder (Platichthys flesus) and mussel (Mytilus edulis) in the Klaipeda-Būtingè area (Baltic Sea). Marine Pollution Bulletin.

BEQUALM, 2005. Biological Effects Quality Assurance in Monitoring Programmes. Available from: <http://www.bequalm.org/about.htm $>$.

Bogovski, S., 1994. Neoplasia in flatfish, particularly in flounders of the Baltic Sea. In: G. Bylund, L.-G. Lönnström (Eds.), Diseases and Parasites of Flounder (Platichthys flesus) in the Baltic Sea, BMB Publication No. 15, pp. 99-104.

Bogovski, S., Lang, T., Mellergaard, S., 1999. Short communication: histopathological examinations of liver nodules in flounder (Platichthys flesus L.) from the Baltic Sea. ICES Journal of Marine Science 56, $152-156$.

Broeg, K., Lehtonen, K.K., this volume. Indices for the assessment of environmental pollution of the Baltic Sea coasts: integrated assessment of a multi-biomarker approach. Marine Pollution Bulletin.

Bucke, D., Feist, S.W., 1993. Histological changes in the livers of dab, Limanda limanda (L.). Journal of Fish Diseases 16, 281-296.

Bucke, D., Vethaak, A.D., Lang, T., Mellergaard, S., 1996. Common diseases and parasites of fish in the North Atlantic: training guide for identification. ICES Techniques in Marine Environmental Sciences No. 19, ICES, Copenhagen.

Feist, S.W., Lang, T., Stentiford, G.D., Köhler, A., 2004. Biological effects of contaminants: use of liver pathology of the European flatfish dab (Limanda limanda L.) and flounder (Platichthys flesus L.) for monitoring. ICES Techniques in Marine Environmental Sciences No. 38, ICES, Copenhagen.

Hosmer, D.W., Lemeshow, S., 2000. Applied Logistic Regression. Wiley, New York, 375 pp.

ICES, 1989. Methodology of fish disease surveys. Report of an ICES Seagoing Workshop held on RV U/F 'Argos' 16-23 April 1988. ICES Cooperative Research Report No. 166, ICES, Copenhagen.

ICES, 1997. Report of the Special Meeting on the Use of Liver Pathology of Flatfish for Monitoring Biological Effects of Contaminants. ICES CM 1997/F:2.

Köhler, A., 1990. Identification of contaminant-induced cellular and subcellular lesions in the liver of flounder (Platichthys flesus L.) caught at differently polluted estuaries. Aquatic Toxicology 16, 271-294.

Köhler, A., Deisemann, H., Lauritzen, B., 1992. Histological and cytological indices of toxic injury in the liver of the dab Limanda limanda. Diseases of Aquatic Organisms 91, 141-153.

Köhler, A., Van Norden, C.J.F., 1998. Initial velocities in situ of G6PDH and PGDH and expression of proliferating cell nuclear antigen (PCNA): sensitive diagnostic markers of environmentally induced hepatocellular carcinogenesis in a marine flatfish (Platichthys flesus L.). Aquatic Toxicology 40, 133-252.

Kopecka, J., Lehtonen, K.K., Baršiene, J., Broeg, K., Vuorinen, P., Gercken, J., Pempkowiak, J., this volume. Measurements of biomarker levels in flounder (Platichthys flesus) and blue mussel (Mytilus trossulus) from the Gulf of Gdańsk (Southern Baltic). Marine Pollution Bulletin.

Kranz, H., Dethlefsen, V., 1990. Liver anomalies in dab Limanda limanda from the southern North Sea with special consideration given to neoplastic lesions. Diseases of Aquatic Organisms 9, 171-185.

Lang, T., 2002a. Fish disease surveys in environmental monitoring: the role of ICES. ICES Marine Science Symposia 215, 202-212.

Lang, T., 2002b. Untersuchungen zu biologischen Schadstoffeffekten bei Nordseefischen: Langzeitdaten zum Auftreten von Lebertumoren bei der Kliesche (Limanda limanda). Informationen für die Fischwirtschaft aus der Fischereiforschung 49, 13-19. 
Lang, T., Dethlefsen, V., 1994. Externally visible diseases and liver neoplasms in flounder (Platichthys flesus) of the southwestern Baltic Sea. In: G. Bylund, L.-G. Lönnström (Eds.), Diseases and Parasites of Flounder (Platichthys flesus) in the Baltic Sea, BMB Publication No. 15., pp. 39-47.

Lang, T., Mellergaard, S., 1999. The BMB/ICES Sea-going Workshop, Fish Diseases and Parasites in the Baltic Sea-introduction and conclusions. ICES Journal of Marine Science 56, 129-133.

Lang, T., Mellergaard, S., Wosniok, W., Kadakas, V., Neumann, K., 1999. Spatial distribution of grossly visible diseases and parasites in flounder (Platichthys flesus) from the Baltic Sea: a synoptic study. ICES Journal of Marine Science 56, 138-147.

Lang, T., Wosniok, W., Bagdonas, E., Baršienè, J., Broeg, K., Förlin, L., Köhler, A., Kopecka, J., Lehtonen, K.K., Parkkonen, J., Pempkowiak, J., Rybakovas, A., Schiedeck, D., Schneider, R. Vuorinen, P.J., in preparation. Multi-biomarker measurements in offshore flounder (Platichthys flesus) from the Baltic Sea.

Lehtonen, K.K., Schiedek, D., this volume. Monitoring biological effects of pollution in the Baltic Sea: neglected-but still wanted? Marine Pollution Bulletin, doi:10.1016/j.marpolbul.2005.11.016.

Lehtonen, K.K., Schiedek, D. Köhler, A., Lang, T., Vuorinen, P.J., Förlin, L., Baršienè, J., Pempkowiak, J., Gercken, J., this volume. The BEEP project in the Baltic Sea: overview of results and outline for a regional biological effects monitoring strategy. Marine Pollution Bulletin.

Malins, D.C., Krahn, M.M., Brown, D.W., Rhodes, L.D., Myers, M.S., McCain, B.B., Chan, S.-L., 1985a. Toxic chemicals in marine sediment and biota from Mukilteo, Washington: relationships with hepatic neoplasms and other hepatic lesions in English sole (Parophrys vetulus). Journal of the National Cancer Research Institute 74, 487494.

Malins, D.C., Krahn, M.M., Myers, M.S., Rhodes, L.D., Brown, D.W., McCain, B.B., Chan, S.-L., 1985b. Toxic chemicals in sediments and biota from a creosote-polluted harbor: relationships with hepatic neoplasms and other hepatic lesions in English sole (Parophrys vetulus). Carcinogenesis 6, 1463-1469.

Malins, D.C., McCain, B.B., Landahl, J.T., Myers, M.S., Krahn, M.M., Brown, D.W., Chan, S.-L., Roubal, W.T., 1988. Neoplastic and other diseases in fish in relation to toxic chemicals: an overview. Aquatic Toxicology 11, 43-67.

Moore, M.J., Myers, M.S., 1994. Pathobiology of chemical-associated neoplasia in fish. Aquatic Toxicology 24, 327-386.

Moore, M.J., Smolowitz, R.M., Stegeman, J.J., 1997. Stages of hydropic vacuolation in the liver of winter flounder Pleuronectes americanus from a chemically contaminated site. Diseases of Aquatic Organisms $31,19-28$.

Myers, M.S., Landahl, J.T., Krahn, M.M., McCain, B.B., 1991. Relationships between hepatic neoplasms and related lesions and exposure to toxic chemicals in marine fish from the US West Coast. Environmental Health Perspectives 90, 17-26.

Myers, M.S., Olson, O.P., Johnson, L.L., Stehr, C.M., Hom, T., Varanasi, U., 1992. Hepatic lesions other than neoplasms in sub adult flatfish from Puget Sound, WA: relationships with indices of contaminant exposure. Marine Environmental Research 34, 45-51.

Myers, M.S., Stehr, C.M., Olson, O.P., Johnson, L.L., McCain, B.B., Chan, S.-L., Varanasi, U., 1994. Relationships between toxicopathic hepatic lesions and exposure to chemical contaminants in English sole (Pleuronectes vetulus), starry flounder (Platichthys stellatus), and white croaker (Genyonemus lineatus) from selected marine sites on the Pacific coast, USA. Environmental Health Perspectives 102, 200214.

Myers, M.S., Johnson, L.L., Hom, T., Collier, T.K., Stein, J.E., Varanasi, U., 1998a. Toxicopathic lesions in subadult English sole (Pleuronectes vetulus) from Puget Sound, Washington, USA: relationships with other biomarkers of contaminant exposure. Marine Environmental Perspectives 45, 47-67.

Myers, M.S., Johnson, L.L., Olson, O.P., Stehr, C.M., Horness, B.H., Collier, T.K., McCain, B.B., 1998b. Toxicopathic hepatic lesions as biomarkers of chemical contaminant exposure and effects in marine bottomfish species from the northeast and Pacific coasts, USA. Marine Pollution Bulletin 37, 92-113.

OSPAR, 1997. JAMP Guidelines for general biological effects monitoring. OSPAR Commission Ref. No. 1997-7.

OSPAR, 2003. JAMP Guidelines for contaminant-specific biological effects monitoring, OSPAR Commission Ref. No. 2003-10.

OSPAR, 2004. OSPAR Coordinated Environmental Monitoring Programme (CEMP). OSPAR Commission Ref. No. 2004-16.

Peters, N., Köhler, A., Kranz, H., 1987. Liver pathology in fishes of the lower Elbe as a consequence of pollution. Diseases of Aquatic Organisms 2, 87-97.

Sandström, O., Larsson, Å., Andersson, J., Appelberg, M., Bignert, A., Ek, H., Förlin, L., Olsson, M., 2004. Integrated fish monitoring in Sweden. HELCOM MONAS Document 3/4, Meeting of the HELCOM Monitoring and Assessment Group, 22-24 March 2004, 32 pp.

Schiedek, D., Broeg, K., Baršiene, J., Lehtonen, K.K., Gercken, J., Pfeifer, S., Vuontisjärvi, H., Vuorinen, P.J., Dedonyte, V., Koehler, A., Balk, L., Schneider, R., this volume. Biomarker responses as indication of contaminant effects in blue mussel (Mytilus edulis) and female eelpout (Zoarces viviparus) from the southwestern Baltic Sea. Marine Pollution Bulletin, doi:10.1016/j.marpolbul.2005.11.013.

Stehr, C.M., Johnson, M.S., Myers, M.S., 1998. Hydropic vacuolation in the liver of three species of fish from the US West Coast: lesion description and risk assessment associated with contaminant exposure. Diseases of Aquatic Organisms 32, 119-135.

Stein, J.E., Collier, T.K., Reichert, W.L., Casillas, E., Hom, T., Varanasi, U., 1992. Bioindicators of contaminant exposure and sublethal effects - studies with benthic fish in Puget Sound, Washington. Environmental Toxicology and Chemistry 11, 701-714.

Stentiford, G.D., Longshaw, M., Lyons, B.P., Jones, G., Green, M., Feist, S.W., 2003. Histopathological biomarkers in estuarine fish species for the assessment of biological effects of contaminants. Marine Environmental Research 55, 137-159.

Vethaak, A.D., Jol, J.G., 1996. Diseases of flounder Platichthys flesus in Dutch coastal and estuarine waters, with particular reference to environmental stress factors. I. Epizootiology of gross lesions. Diseases of Aquatic Organisms 26, 81-97.

Vethaak, A.D., Jol, J.G., Meijboom, A., Eggens, M.L., Rheinallt, T., Wester, P.W., van de Zande, T., Bergman, A., Dankers, N., Ariese, F., Baan, R.A., Everts, J.M., Opperhuizen, A., Marquenie, J.M., 1996. Skin and liver diseases induced in flounder (Platichthys flesus) after long-term exposure to contaminated sediments in large-scale mesocosms. Environmental Health Perspectives 104, 1218-1229.

Vethaak, A.D., Rheinallt, T., 1992. Fish disease as a monitor for marine pollution: the case of the North Sea. Reviews in Fish Biology and Fisheries 2, 1-32.

Vethaak, A.D., Wester, P.W., 1996. Diseases of flounder Platichthys flesus in Dutch coastal and estuarine waters, with particular reference to environmental stress factors. II. Liver histopathology. Diseases of Aquatic Organisms 26, 99-116.

Vuorinen, P.J., Keinänen, M., Vuontisjärvi, H., Barsiene, J., Broeg, K., Förlin, L., Gercken, J., Kopecka, J., Köhler, A., Parkkonen, J., Pempkowiak, J., Schiedek, D., this volume. Use of biliary PAH metabolites as a biomarker of pollution in fish from the Baltic Sea. Marine Pollution Bulletin, doi:10.1016/j.marpolbul.2005.11.020.

Wiklund, T., Bylund, G., 1994. Diseases of flounder (Platichthys flesus (L.)) in Finnish coastal waters. In: G. Bylund, L.-G. Lönnström (Eds.), Diseases and Parasites of Flounder (Platichthys flesus) in the Baltic Sea. BMB Publication No. 15, pp. 49-52. 